\title{
Challenges of COVID-19: Preschool Teachers' Views and Experiences During the Quarantine
}

\author{
Gökhan GÜNEŞ ${ }^{1}$, Mehmet TORAN $^{2}$
}

\begin{abstract}
The purpose of the study is to analyze the evidence gathered from the preschool teachers' experiences during the COVID-19 pandemic quarantine. The study was carried out with 11 teachers who have professional experience ranging between 3 to 19 years from private and public preschools. The study was specified according to criterion sampling strategy under the purposeful sampling method. The data gathered via open-ended questions and the phenomenology method, one of the qualitative research designs, was used. The qualitative content analyses technique was applied for analyzing the data. It was reached remarkable themes about the preschool teachers' pedagogical challenges during the COVID-19 pandemic based on the analysis of data. The themes and their subthemes are as follows: The theme "challenges in the distance education process" contains the sub-themes of children, teachers, and parents, the theme "views about educational policy in new normal" contains the sub-themes of technological infrastructure problems, unpreparedness, and negative attitudes, the theme "expectations for the improvement of distance education" contains the sub-themes of teacher training, effective family involvement activities, and technology-based programs.
\end{abstract}

Keywords: COVID-19 pandemic, Preschool teacher, Quarantine challenges, Early childhood education, Unpreparedness

\section{COVID-19’un Zorlukları: Okul Öncesi Öğretmenlerinin Görüşleri ve Karantina Sırasındaki Deneyimleri}

Öz: Çalışmanın amacı, okul öncesi öğretmenlerinin COVID-19 salgını dönemi karantinasındaki deneyimlerinin
incelenmesidir. Araştırma, özel ve resmi anaokullarından 3 ile 19 yıl arasında değişen mesleki deneyime sahip 11 öğretmen
ile yürütülmüştür. Araştırmada yer alan katılımcllar, amaçlı örnekleme yöntemi kapsamında ölçüt örnekleme tekniğine göre
belirlenmiştir. Çalışmada veri toplama aracı olarak açık uçlu görüşme soruları kullanılmıştır. Araştırmada nitel araştırma
yöntemlerinden fenomenoloji yaklaşımı tercih edilerek verilerin analizinde içerik analizi tekniği kullanılmıştır. Çalışmada,
okul öncesi öğretmenlerinin COVID-19 salgını sürecinde karşılaştıkları pedagojik zorlukları açıklayan dikkat çekici temalara
ulaşıllmıştır. Okul öncesi öğretmenlerinin karantina döneminde karşılaştığı zorlukları; "uzaktan eğitim sürecindeki
zorluklar", "yeni normalde eğitim politikasına ilişkin görüşler" ve "uzaktan eğitimin iyileştirilmesine yönelik beklentiler"
temalarıyla ortaya koymaktadır. Genel temalardan uzaktan eğitim sürecindeki zorluklar; çocuk, öğretmen ve aile alt
temalarından, yeni normalde eğitim politikasına ilişkin görüşler; teknolojik alt yapı eksikliği, hazırlıksız yakalanma ve
olumsuz tutumlar alt temalarından ve uzaktan eğitimin iyileştirilmesine yönelik beklentiler genel teması da öğretmen eğitimi,
etkili aile katılımı ve teknoloji temelli programlar alt temalarından oluşmaktadır.

Anahtar Sözcükler: COVID-19 salgını, Okul öncesi öğretmeni, Karantina güçlükleri, Erken çocukluk eğitimi, Hazırlıksızlık

\footnotetext{
${ }^{1}$ Mersin University, Early Childhood Education Department, Mersin, Turkey, e-mail: gokgunes@mersin.edu.tr, ORCID ID: https://orcid.org/0000-0002-8923$\underline{3315}$

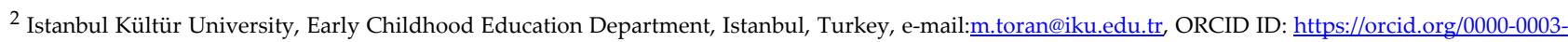
$\underline{3457-9113}$
} 
Due to its worldwide spread and severity, the novel coronavirus (COVID-19) outbreak was declared a pandemic by the World Health Organization (WHO) on 12 March 2020 (WHO, 2020a). As part of the policy measures to combat the pandemic, in April 2020, schools at all levels were closed in 191 countries, and 1.7 billion students were affected by this decision (UNESCO, 2021). Following the closure of schools, many countries switched to distance education in order to continue education. A report published by UNICEF (2021) on 5 September 2020 states that $90 \%$ of countries switched to distance learning at the levels of primary school and beyond, whereas this number was $60 \%$ for preschool education. The report also states that despite these numbers, not all children had equal access to education and that educational inequality became more prominent during the pandemic. In developing and underdeveloped countries, the teachers had low levels of technology literacy, as well as difficulty accessing the necessary technology (UNESCO 2020a).

After a COVID-19 case was detected in Turkey, schools were closed on 16 March 2020. Preschool to secondary schools began distance education a week later, and universities followed suit three weeks later (Koyuncu \& Düşkün, 2020). 24.9 million students were affected by the closure of schools and the subsequent implementation of distance education due to the pandemic, among which 1.3 million were children receiving early childhood education (UNESCO, 2021). From 22 March 2020 until the summer break, preschools, like other institutions of education, provided asynchronous distance education via the Internet and TV. In-person teaching was gradually reintroduced in September 2020, and it fully resumed in October 2020. However, due to the uncontrollable spread of COVID-19 and the rapid spike in case numbers, distance education needed to be reinstated in December (Ministry of National Education [MoNE], 2020a, 2020b). On the other hand, with economic concerns rising, private preschools started to consider resuming in-person teaching, thus creating a discrepancy between private schools and state schools regarding their approach to distance and in-person education. This caused anxiety and uncertainty in teachers due to the discrepancy in their sector ${ }^{1}$.

While some countries developed policies to ensure the continued in-person education of early childhood aged children, others relied fully on distance education during the COVID-19 pandemic (UNESCO, 2021; Visnjic-Jevtic et al., 2021). In those countries where preschool education was carried out remotely, teachers, parents, and students were faced with a different learning environment for the first time. This new environment has sparked debates about various topics, such as access to technology and Internet connection, teachers' competence and the parents' role in, and the children's adaptation to distance education. Studies on early childhood distance education experiences have shown that the preschool teachers' incompetent use of technology (Kim, 2020), disuse of distance education methods and techniques (Atiles et al., 2021; Quezada et al., 2020), low levels of digital literacy (Pavlenko \& Pavlenko, 2020), and limited online activities (Inan, 2021) are deciding factors on the effectiveness of distance education. Furthermore, limitations to the effectiveness of distance education at the early childhood level are found to be the parents' shortcomings in supporting their child, assuming an intermediary role between their child and the teacher, difficulty balancing housework with tracking the child's learning process, and the change in the family's routine (Dong et al., 2020; Lau \& Lee, 2020; Mantovani et al., 2021); and assuming an educator role in their child's distance education despite not having the necessary pedagogical competencies (Garbe et al., 2020; Parczewska, 2020). At the same time, the children's lack of necessary skills to operate the digital tools, difficulty in participating in the online activities without parental supervision (Alan, 2021; Inan, 2021; Lau \& Lee, 2020; Yıldırım, 2021), and inability to sit still in front of a screen for long periods (Samuelsson et al., 2020) have been cited as other issues faced during distance education at the early childhood level. Hu et al. (2020) reported that the children's increased passive screen time was negatively impacting their academic development, as well as their social and cognitive development.

Further to the issues experienced in distance education practices in preschool education, studies (Andrew et al., 2020; Bayrakdar \& Guveli, 2020) and reports (United Nations, 2020a, 2020b; UNESCO, 2020a; UNICEF, 2021) have also revealed issues relating to unequal access to distance education. It has been determined that socioeconomic differences make inequalities in access to technology more visible in distance education at the early childhood level (Atiles et al., 2021), that home learning creates more unequal conditions

${ }^{1}$ Researchers field interviews and observations. 
than learning at preschools (Barnett et al., 2021), and that in those countries where pandemic preparedness was insufficient, both teachers and students have had difficulties accessing the necessary technology, and the schools were not able to offer adequate technological infrastructure (Akkaş et al., 2020; Andrew et al., 2020; Malta Campos \& Vieira, 2021; Visnjic-Jevtic et al., 2021).

\section{Significance and Purpose of The Study}

Considering the COVID-19 pandemic within the framework of education, its adverse effects, and its unpredictable and uncontrollable nature proves it to be a crisis, which brings about a need for preparedness to overcome it. The concept of preparedness is situated at the center of all crisis-related paradigms, and it has a preventive and dynamic structure that facilitates, includes social dimensions, and has predictive qualities (Staupe-Delgado \& Kruke, 2018). In this context, to overcome the crisis in education caused by the pandemic, policies need to be developed based on concrete findings by trying to understand the current situation. The frequent changes made to the distance education policies in Turkey during the pandemic (MoNE, 2020a; 2020b), and the limited number of studies conducted on this issue (Akkaş et al., 2020; Alan, 2021; Inan, 2021; Yildırım, 2021) make it difficult to understand the current situation using concrete findings. Particularly, the lack of comprehensive studies on the personal experiences and views of preschool teachers, who are responsible for conducting distance education activities during the pandemic, creates challenges for understanding the current situation and poses serious obstacles in determining the needs that will arise in future policy development. Considering this, the purpose of the present study was to analyse the evidence gathered from the preschool teachers about experiences during the COVID-19 pandemic.

The present study shows that the adverse effects of the COVID-19 pandemic can be observed in the field of education as in many other areas, and the development of new normal in line with the nature of the pandemic is needed. In this context, defining how preschool teachers understand, perceive, and experience the pandemic phenomenon with a collective perspective will predict the success of the adoption and execution of an education concept featuring new normal such as hybrid models, distance education (lectures/activities via online and/or TV), distancing and masks.

\section{Method}

\section{Research Design}

The study adopts the qualitative paradigm as it provides effective and profound results by examining the participants' points of view of their experiences, interpretations, and perspectives (Creswell, 2014; 2009; Hammarberg et al., 2016). According to Creswell (2014) research based on qualitative method aims to develop a complex picture of the problem or issue under study via a holistic approach. This process involves multiple perspectives, identifying the many factors involved in a situation, and generally sketching the larger picture that emerges. A visual model of many facets of a process or a central phenomenon aids in establishing this holistic picture (Creswell \& Brown, 1992). The narrative studies, phenomenology, grounded theory, ethnography, and case studies are applied as research methods under the qualitative design (Creswell, 2014).

Phenomenology research design is widely used as one of a qualitative research method which aims to link people's perspectives, perceptions, and experiences between phenomena (Patton, 2002). According to Husserl (1913/1983) phenomenology is a perspective of science which enables to understand human beings at a deeper level by gazing at the phenomenon. It is worthy of notice that as Creswell (2014) and Merriam (2009) emphasized the participants' perspectives are the ones we seek to investigate and understand, not those of the researcher. Patton (2002) stated that researchers try to reveal how participants perceive, describe, feel about, remember, and make sense of the experience shared. Creswell (2014) draws attention to phenomenology as a method in which the relationship between philosophy and psychology which interested in thoughts, views, and experiences of humans about the real world, life, and phenomena, which is reflected effectively. The experiences of several individuals who have all experienced the phenomenon are centred in this design which has strong philosophical underpinnings and typically involves conducting interviews (Giorgi, 2009; Moustakas, 1994). 
The researchers collect data directly from the phenomenon being studied (Creswell et al., 2007) in line with the purpose of the study which to examine how teachers bring together the COVID-19 fact that they experience in understanding the situation during quarantine. For the present study, determining the participants' inferences, conceptualization, experiences, and comprehension plays an important role in defining the diversity of realities of the COVID-19 phenomenon experienced by teachers in the context of the necessity of pedagogical potential and knowledge fields (Marton, 1981). Providing the qualitative research indepth analysis on participants' experiences and perceptions and meanings attached to a phenomenon (Creswell, 2007) and enabling phenomenology to bring the facts with participants' experiences and perceptions (Patton, 2002), was effective in determining study design.

\section{Participants}

Considering that purposeful sampling is widely used in qualitative research for the identification and selection of information-rich cases related to the phenomenon (Palinkas et al., 2015) via the most effective use of limited resources (Patton, 2002), the sample of the study was specified according to criterion sampling strategy under the purposeful sampling method. Patton (2002, p.230) described purposeful sampling as "the logic and power of purposeful sampling lie in selecting information-rich cases for study in depth. Information-rich cases are those from which one can learn a great deal about issues of central importance to the purpose of the inquiry, thus the term purposeful sampling. Studying information-rich cases yields insights and in-depth understanding rather than empirical generalizations". Using the limited resources effectively (Patton, 2002), identifying and selecting participants which are knowledgeable about or experienced with a phenomenon of interest (Creswell \& Plano Clark, 2011) and availability and willingness to participate, and the ability to communicate experiences and opinions in an articulate, expressive, and reflective manner (Bernard, 2002; Spradley, 1979) are accepted as the method's strengths (Palinkas et al., 2015). The criterion sampling strategy is based on predetermined criteria (Merriam, 2009; Patton, 2002), which plays an important role in the effective implementation of the purposeful sampling method. Thus, there were three criteria of sampling determined in the current study which carried out with preschool teachers. Firstly, responsible for running distance education in the pandemic. Secondly, at least have two years professional experiences (in our country the candidate processes of teachers are completed after a year of work). Finally, living and teaching in İstanbul are the last criteria for selecting the sample. İstanbul had the highest number of COVID-19 cases has the largest population in Turkey, which makes it highly representative, and was the first city to implement a lockdown.

The study was carried out with 11 preschool teachers (10 female and a male) from the public (six participants working) and private (five participants working) educational institutions in 2020/2021 academic year. Moreover, two of the preschool teachers have master's degrees and nine have bachelor's degrees and their professional experience ranging between 3 to 19 years.

\section{Data Collection Tool, Procedures and Data Analyses}

The data collection tool used for the study was devised considering which data collection and analysis steps were appropriate for the nature of the research design. Furthermore, the content validity of the interview formats that were used was vetted by experts' opinions. There were two academicians, have contributed the content validity of the interview questions, have doctorate degrees in early childhood education and one of the experts has 16 and the other one has 22 years of experience. The necessary updates were made following the pilot applications that carried out with a preschool teacher who has nine years professional experiences and questions were asked when deemed necessary during the interview to better understand the perceptions of the teachers. In the interview form prepared in accordance with the purpose of the study, the participants were asked questions about their personal experiences during the quarantine, the quality of the education they received during their teacher training, the adequacy of teacher training policies and applications in crises, their observations on the children's experiences, their perspective on the new normal, and their views on the children's needs during the quarantine.

The current study was conducted according to Creswell's (2007) stages of the phenomenological 
research study. Creswell (2007) listed five steps in the application process of phenomenological study. First, the determination of appropriates the research problem to the phenomenological approach. Second, a phenomenon is identified pertinent to the research question. Third, the data collection process by the help of in-depth interviews and multiple interviews as phenomenological interviews with samples who have experienced the phenomenon. The fourth step is data analysis which included develop clusters of meaning from these statements into themes. These themes, at the final stage of a phenomenological study, will provide a backbone for a description that presents the essence of the phenomenon. In other words, the last step is presented a meaningful phenomenological description, models or patterns that reflect participants' feelings, thoughts, or views. In the current study, researchers try to explain preschool teachers' pedagogical challenges during the COVID-19 pandemic from themes which were gained after the data analyzing process.

The data collection process includes 11 interviews lasting no less than half an hour (meanly 46 minutes and totally 513 minutes). It is known that interviews enable to reveal behaviors, feelings and views that come from participants' perspectives and experiences (Creswell, 2014; Giorgi, 2009; Merriam, 2009; Moustakas, 1994; Patton, 2002). During the data collection process, the pandemic conditions were considered and individual interviews with the participants were held over remote video call programs. The interviews were recorded with the participants' consent and the transcription process was carried out independently by the researchers with repeated analyses. Qualitative content analysis, one of the several qualitative methods for analyzing data and interpreting its meaning (Schreier, 2012) and enables a systematic and objective means of describing and quantifying phenomena (Downe-Wamboldt, 1992; Schreier, 2012), was used in the current study. According to Elo and Kyngäs (2008), for success in the application of qualitative content analyses, data can be reduced to figure out the phenomenon via creating categories, concepts, a model or a conceptual map.

\section{Validity and Reliability}

In this research several strategies were used for validity and reliability. Firstly, the researchers sought the relevant literature for preparing the semi-structured interview form, got experts opinions for the prepared questions, and finalized the semi-structured interview form for the pilot study according to experts' opinions. Secondly, pilot interviews were carried out with two preschool teachers before starting the interview process and the semi-structured interview form was revised in accordance with their responses. Lastly, more than one interview was carried out with preschool teachers participating in the research. Additionally, strategies such as sharing the data with participants for their confirmation, dealing with the data for a long time, making indepth descriptions, using the participants' expressions without changing them, and checking several times the notes and audio recordings were used for validity and reliability.

Creswell (2014) stated that objectivity and truthfulness are important to qualitative and quantitative research. In general, believability, based on coherence, insight and instrumental utility and trustworthiness (Lincoln \& Guba, 1985) through a process of verification rather than through traditional validity and reliability measures. Although several trustworthiness evaluation criteria have been used for qualitative studies (Creswell, 2014; Schreier, 2012), researchers followed Elo et al. (2014) strategy which consists of three phases such as preparation, organization, and reporting, to improve the trustworthiness of content analysis in the current study. A checklist (Elo et al., 2014, p. 3) is appropriate on the nature of qualitative research design (Creswell, 2014; Merriam, 1992; Patton, 2002), was used by researchers to the trustworthiness of the content analyses in the current study.

It was attention that the results of content analysis were linked to transferability, conformability, and credibility. After the transcription process, researchers came up with themes and sub-themes independently and compared their codes with each other. Moreover, repeated comparison of checklist developed by Elo et al. (2014) trustworthiness of content analyses and received consultancy from experts who contribute the content validity of the interview questions. In other words, comparison of themes and sub-themes come from content analyses results were checked repeated and evaluated by two researchers independently. We reported our findings systematically and carefully and controlled connections between data and results (Elo et al., 2014). 


\section{Ethical Process}

The ethical permission form number is 2020.52 and was signed by the chair of the ethics committee of the second author's university. In addition to ethical consent, informed consent forms were collected from all individual participants included in the study.

\section{Findings and Discussion}

The research findings and related discussions were presented under the headings according to the analysis of the data obtained from the interviews.

\section{Challenges in The Distance Education Process}

The challenges experienced by preschool teachers in distance education during the quarantine emerged in three areas. These areas are the children's access to and use of distance education tools, the parents' access to and use of distance education tools, and the proficiency of the teacher's technological and pedagogical field knowledge.

\footnotetext{
...The children could not use the Educational Informatics Network (EIN) [EIN, is developed by the MoNE the Digital Education Platform of Turkey, is a social education platform offering a reliable and personalized learning environment for all K-12 students. It offers curriculum-based learning content as well as personal and professional development content to the users. EIN is pronounced as EBA in the national language and was used as EBA in this study] platform provided by the state, we could not do anything with them remotely, some of the children did not have tools such as computers anyway, so I tried to send them the activities via WhatsApp, they could not access EBA, we could not do the live lessons (Teacher 10).

...There's the EBA system the state uses; we did not use that at all at our preschool. Our students could not log in, they did not have access, I mean, the state should provide the technical infrastructure to deal with these technical issues... Our students and I could not access EBA. We were last in the order of importance as the preschools. We tried to send the activities via WhatsApp (Teacher 7).
}

The statements made by Teacher 10 and Teacher 7 indicate that the children had difficulties participating in distance education and could not use the infrastructure and tools provided for distance education or had trouble accessing these tools. Furthermore, the statements reveal that, as the students were unable to access distance education tools and programs, the teachers tried to manage by using instant messaging apps. The teachers said they observed that the children faced the following difficulties during the distance preschool education they received in quarantine: limited access to distance education, difficulty accessing digital tools, and insufficient skills to use the digital distance education tools. These findings are supported by remarkable report, which was prepared by Human Right Watch [HRC] (2021), based on over 470 interviews with students, parents, and teachers from 60 countries between April 2020 and April 2021. According to this report's results, opportunities, tools, and access to continuing children's learning process during the COVID-19 pandemic were not supplied to children (HRC, 2021). Similarly, Murgatrotd (2020) stated that accessibility is also a problem among other challenges such as affordability, flexibility, learning pedagogy, life-long learning, and educational policy during the COVID-19 pandemic. Moreover, Atiles et al. (2021) drawn attention to preschool teachers' concern about the materials needed for the young children to complete activities and assignments that have to be supplied to families. Furthermore, Pokhrel and Chhetri (2021) emphasized accessibility problems of distance education in their study conducted a literature review on the impact of the COVID-19 pandemic on teaching and learning. The instructor's or students' technological abilities to access online sites and use computers (Kim, 2020) also children or school-age students do not have online access or have limited experience with online learning tools, such as computers (Fedynich, 2014; Wedenoja, 2020) have been accepted as a limitation of distance education before, during and post COVID-19. Although most countries have digital resources and platforms that can be accessed remotely, which have been bolstered with unprecedented speed by the ministries of education (UNESCO, 2020b), uneven distribution of resources and strategies result in unequal access an Internet connection by lower-income groups (RiebleAubourg \& Viteri, 2020). UNICEF (2020) reported 40 per cent of countries did not provide remote learning opportunities at the pre-primary level of education. 
Another challenge faced by preschool teachers during distance education was that the parents had trouble accessing and using the necessary technology to help their children with the distance education process. The difficulties experienced by parents during the distance education process were strikingly revealed in these statements made by Teacher 8 and Teacher 6 .

\begin{abstract}
We constantly sent the parents activities for the children through EBA, but they could not make much use of these, some of them did not have computers. They usually prefer using WhatsApp, it is easier to reach, the parents find it easier (Teacher 8).
\end{abstract}

We used Zoom once, but we got limited use out of it. The parents are not very experienced with that so we preferred WhatsApp. We tried to get the children to do the activities at home in this way, but I do not think the parents provided much support (Teacher 6).

According to the teachers, another reason why they had difficulties during the distance education process was that the parents had trouble supporting their children at home. Furthermore, this support was not sufficient due to the limited use of technology, and some parents had difficulty accessing this technology at all. The pressure has increased on families to support their child's learning during pandemic after switching to distance education (Stites et al., 2021). Even some parents get stressed when they have to take on the role of the teacher (Atiles et al., 2021). It was reported that families have not sufficient training or supplies to deliver online lessons, and zoom lessons not being developmentally appropriate for pre-schoolers (Stites et al., 2021). In addition to preschool families' negative views towards distance education have already reported (Dong et al. 2020), children have difficulty following distance education and completing tasks without their parent's help (Lau \& Lee, 2020). Although it is very important to parents' role on distance education, parents have some difficulties with technological expertise (Abuhammad, 2020). Garbe et al., (2020) emphasized that some prepandemic problems such as accessibility (Hollingworth et al., 2011), lack of involvement caused by economic conditions (Hohlfeld et al., 2010), low level of digital self-efficacy (Povey et al., 2016) and lack of interest in using technology (Beckman et al., 2019) have affected families during the COVID-19 Pandemic.

The interviews revealed that, much like the parents and the children, preschool teachers also experienced difficulties during the distance education process. These difficulties can be understood by the statements of Teacher 6 and Teacher 9.

\footnotetext{
We actually don't know much about distance education either. It's because this is our first time experiencing this too. I believe we should also receive training about this. We suddenly found ourselves in the middle of distance education. At first, we struggled since we weren't experienced. I had no idea what I could do when it comes to technology. Then, it became very ordinary and very monotonous. So, I don't think it was very fruitful (Teacher 6).

Of course, we had never done distance education before. I was a little inadequate on that front, as we found out, so that was a new development for us. It is also up for debate how successful we were (Teacher 9).
}

The preschool teachers stated that they faced challenges such as being inexperienced with distance education, feeling unequipped to deal with the situation, and being unable to use distance education tools adequately. They also revealed that they could not develop digital content for the children nor sustain the distance education process. These challenges can be seen as international challenges rather than local challenges. Because same challenges were classified as a digital gap by the US Department of Education (2017) in three categories as access gap (socio-economic status of the school, geography, household income), the pedagogical skills and digital literacy gap (Holland, 2018); and the usage gap (opportunities to use technology actively for both teachers and students) (Jain et al., 2021). These three digital gaps have turned into challenges faced by teachers during the pandemic. It is also known that most early childhood teachers use limited digital technologies such as show pictures or videos in their teaching. But they have to instruct via a digital platform such as Google Classroom, Zoom, Microsoft Teams, and others when the COVID-19 outbreak. If preschool teachers want to teach via distance education, they have to improve their digital skills and need to take on additional roles (Kalogiannakis, 2010). In addition to taking on additional roles (i.e. digital content developer and practitioner) and developing digital skills, the teacher has also to be specialized in digital pedagogy.

\title{
Views About Educational Policy in New Normal
}

The challenges experienced by preschool teachers throughout the distance education process in 
quarantine also paved the way for the formation of ideas regarding educational policies applied during the quarantine and the new normal. The participants gave their opinions on educational policies in the new normal, technical infrastructure issues, inadequate preparation for providing education in the new normal, and negative experiences with distance education. The statements of Teacher 1 and Teachers 3 are followings:

I believe the fact that the state left the whole process in the teachers' hands created inequalities because some teachers took the initiative to communicate with the children, whereas others merely sent files to the family through EBA and did those activities. I believe this brought on the inequality of opportunity. It is quite tragic that these children were faced with such inequality at the start of their life. I think they were restricted from education, which is their most basic right. [The children] did not have access [to education] (Teacher 1).

I don't think [the educational policies throughout the pandemic] were sufficient. I presume they provided education through EBA but attendance was not taken so it was not known whether the children attended the classes. ...I think public schools did not provide any opportunities (Teacher 3).

In addition to challenges about inadequate technological infrastructure, other challenges can be categorized as physical conditions of schools were stated by Teacher 6 and Teacher 7 .

First of all, I do not think the physical conditions at schools were suitable for this... They are telling us that they will reduce the hours, but it is impossible for the kids to constantly wear those masks... I do not think that the new normal can be implemented well in preschools (Teacher 6).

I mean, I do not think it will help to overcome this crisis. Of course, there can be some adjustments according to the new normal, like reducing class sizes, not seating children next to each other, adhering to distancing rules, wearing masks in class, etc. But I do not know how successful we will be, and I actually do not believe we will be all that successful. We will wait and see (Teacher 7).

Teacher 1 and Teacher 3's views on the distance education provided during quarantine reveal the belief that there were inequalities of opportunity especially brought on by inadequate technological infrastructure, and that these inequalities were exacerbated by the policy of leaving the process to the teachers' initiatives, which in a way signals a lack of policy. Furthermore, the unsustainability of the policies was revealed by the fact that the teachers viewed the educational policies to be inadequate, the crisis was not managed adequately, and the children were not followed closely. When the opinions about the educational policies in the new normal were evaluated, it was emphasized that the physical conditions of the preschools were not suitable for the new normal, the crowded classes may be a problem, and the activities prepared normally were not appropriate (see comments of Teacher 6 and Teacher 7). Technological and physical infrastructure problems in pre-school institutions are among the difficulties encountered during the pandemic process, which makes policy development important in this direction. Our findings about educational policy have been discussed by international organizations (Rieble-Aubourg \& Viteri, 2020; UNICEF, 2020; UNESCOa, 2020; World Bank, 2021; WHO, 2020b). For instance, Hincapié et al. (2020, p.9) from Inter-American Development Bank lists the five strategies followed in the Plan Ceibal, which is implemented as a policy within the scope of Uruguay's infrastructure development efforts, as follows:

- making tablets available to families (loans and use varied from center to center)

- setting up early education platforms and applications for parents to download on personal devices

- developing the "Ceibal at Home" strategy for keeping teachers, children, and most of all families in communication (for example, through emails to parents or mass social media campaigns) to familiarize them with the Plan's resources, with how to use the technology, and with socioemotional learning

- creating a "teacher space" as part of the education management system to provide teachers with digital resources, with specific activities organized by age

- offer access to digital books via the Biblioteca País, which holds over 7000 titles for children of all ages

Moreover, WHO (2020b, p.3) recommend some regulation to school's classroom according to COVID19 Pandemic as follows:

- Physical distancing where appropriate

- Wearing of masks, where recommended 
- Frequent hand hygiene

- Respiratory etiquette

- Cleaning and disinfection

- Adequate ventilation

- Spacing of desks or grouping of children if required.

\section{Expectations for The Improvement of Distance Education}

Preschool teachers developed solutions to deal with the difficulties they experienced with distance education in quarantine, as well as came up with suggestions to improve distance education. These suggestions centered around improving teacher training, developing technology-based education programs, and conducting family involvement activities effectively.

It was emphasized that preschool teachers lacked the necessary competencies to deal with a potential crisis, and teacher training programs needed to be enriched in the context of both crisis management and technology use. Further emphasis was placed on the fact that teacher training and in-service training programs needed to be updated and designed to fit the current needs in order to train teachers to have the necessary pedagogical competencies. Teachers 6, 7, and 10's statements strongly support these points.

Additional courses on how the teachers can educate the children on technology, how they can help them can be added to the curriculum. Because technology is a part of all aspects of our life now. The children are leagues ahead of us but as their teachers, we need to be educated on how to make technology more fun and how to utilize it. They need to be taught about this during their undergraduate degree, the curriculum needs to change. Perhaps, it needs to be an additional course (Teacher 6).

Of course, I do not think this. Of course, we need to adapt. We need to keep up with the times. A lot has changed since then, 12-15 years have passed, time is passing, technology is advancing, and we need to keep up with technology, we need to renew ourselves and keep up (Teacher 7).

We had computer lessons, of course, we've been using technology a lot but this has not been enough. I've felt very incompetent throughout this process, I haven't been able to do much, I haven't known how to deal with the situation, teacher training programs need to be improved in this regard... (Teacher 10).

It is known that some preschool teachers are not familiar with digital pedagogy (Jain, 2021), they find using technology is difficult (Lindahl \& Folkesson, 2012), and they resist to adapt new conditions (Mudi, 2020). According to Kalogiannakis (2010), these difficulties originated from the gap between the Information and Communication Technology (ICT) courses in the pre-service teacher training program and the level of knowledge and use that can respond to current conditions. It is recommended well-designed ICT courses which are different from the traditional approach applied in teacher training programs to overcome these challenges (Chen \& Chang, 2006; Kerry \& Farrow, 1996; Kim, 2020).

It was determined that preschool teachers had the most contact with the parents during the distance education process. The teachers stated that the parents played an active role in the education process as they actively supported their children at home during the distance education process, and in a way took on the role of assistant teacher. However, during this process, the teachers could not communicate effectively with the parents, and the parents could not give adequate instructions to their children, and this influenced the education of the child. Regarding the roles of parents in the education process, the participants emphasized the need for organizing effective family involvement activities and supporting families in assisting their children with their education. Also, as previously highlighted so many families get stress being teacher or teacher assistant (Atiles, 2021). Statements made by Teachers 5 and 11 put a clear emphasis on these points.

...at this point, the parents are everything to the children at home. Teachers should at least support the parents in gaining the necessary knowledge and skills in order to convey the importance of planning out the days. They should also let them know how important the parents' support is in terms of self-regulation (Teacher 5).

...the parents tell the children what they know, so what the child plays is limited to what the parents know... When we ask them how they spend time with their child, we usually get a response like "I hang out and they hang out with me". Seeing how the parents choose to treat their children, I do not think the children, I mean most of them, spend quality time, I do not think these children are supported. Teachers should establish cooperation with the families based on mutual learning on how to support the child (Teacher 11). 
It was understood that the preschool teachers faced challenges with continuing education during the quarantine and distance education that started with the COVID-19 pandemic. The source of these challenges was primarily the teachers, but the children and the parents also played a role. Furthermore, technological insufficiencies, insufficient use of technology in education, and lack of practical application of state policies were other contributing factors. Better teacher training increased technological literacy, and support for teachers regarding family involvement activities were cited as suggestions for overcoming these difficulties. Similar to our findings, Arcia et al. (2021) from World Bank Group Education drawn attention to the necessity of powerful programs of preschools which enable provide teachers with pedagogical support, guidance on child's cognitive development, link positive interaction between parent and child, and also support learning continuity. In addition, to expand access to digital pedagogy and provide academic and technical support (Arcia et al., 2021), it was also emphasized that supporting parents for helping children's learning process at home plays an important role to minimize learning losses. For instance, the Read@Home, funded by the World Bank in North Macedonia, used by 40.000 children between the ages 3 to 12, can be seen as a solution for minimizing the learning losses (Naceva et al., 2020). The World Bank (2021) introduces the Read@Home program as follows:

\section{deliver reading, learning and play materials to hard-to-reach homes, as quickly and efficiently as possible, and encourage parents and others to support children's learning at home. The initiative targets families (with children age from 3-12) who are unlikely to be reached with the remote learning approaches being rolled out by ministries of education and encourages use of mother-tongue as much as possible.}

It is thought that it can provide a holistic and multidimensional response to the challenges encountered in the pandemic, with the spread of such programs, which support the learning processes of children at home by providing both materials and parent involvement all over the world.

\section{Preschool Teachers' Pedagogical Challenges During COVID-19 Pandemic}

The result of the qualitative content analysis of the teacher opinions gathered with the interview forms that were filled out as part of the study, is presented in Figure 1.

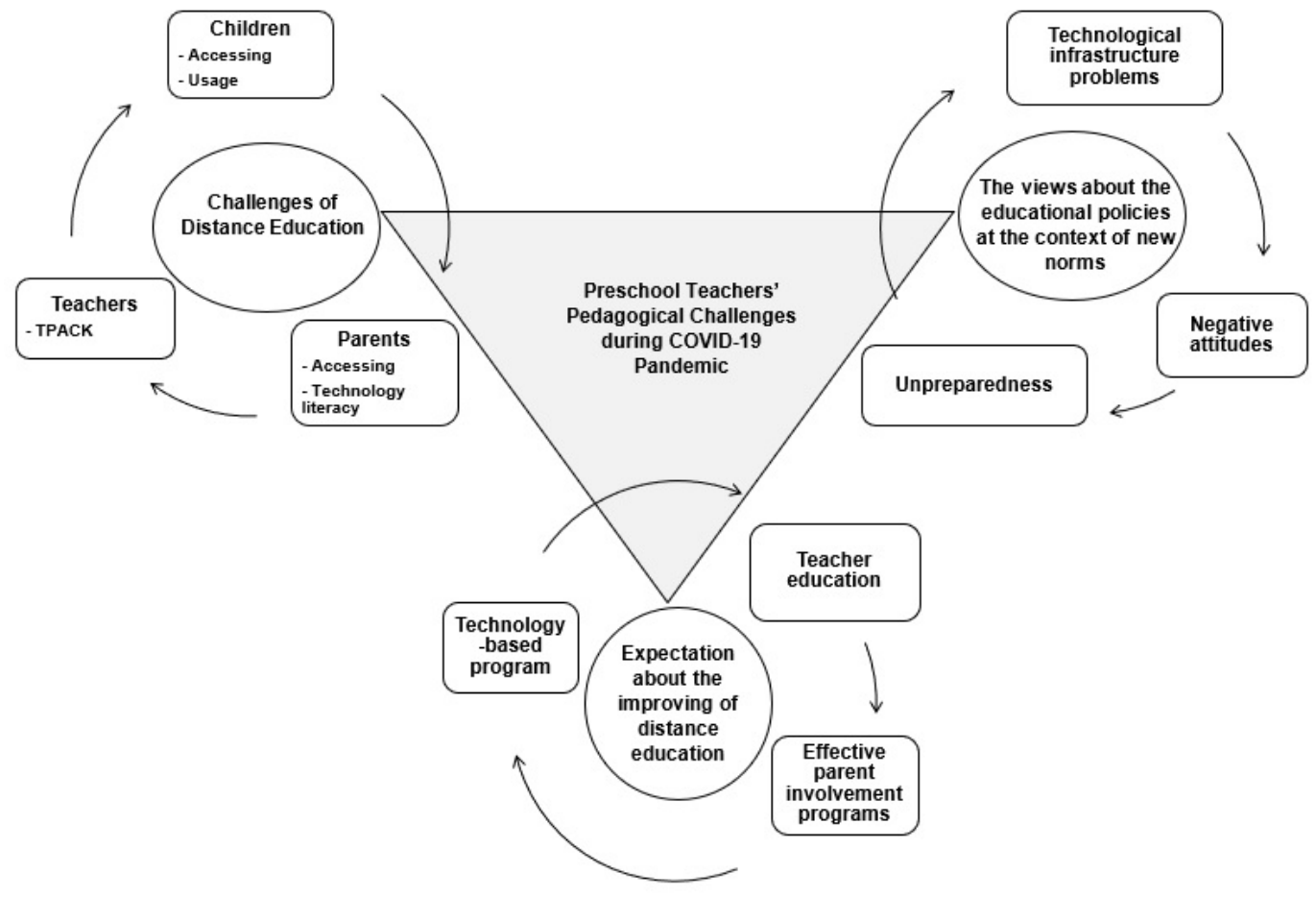

Figure 1. Preschool teachers' pedagogical challenges during the COVID-19 pandemic.

In Figure 1, challenges experienced by preschool teachers during the COVID-19 pandemic are outlined 
under three dimensions, namely challenges with distance education, educational policies in the new normal, and improvements to distance education. The findings show that improving teacher training policies, providing technical support to families, strengthening technological infrastructure, not being caught unprepared for possible scenarios and unexpected situations from a multidimensional and holistic perspective.

The problems experienced by families regarding the value and applicability of distance education during the COVID-19 pandemic (Dong et al. 2020), as well as the families' quarantine process, their feelings of stress due to difficulties with balancing work and aiding their children's education and their need for support (Spinelli et al., 2020) were all clearly emphasized by the participants of the present study. Furthermore, study results reporting the fact that nearly $85 \%$ of 3275 Chinese children had experiences with online learning that lasted less than half an hour at a time (Dong et al. 2020) coincide with the present study's findings of children's access to and use of technology. The present study's findings relating to issues brought on by teachers' low levels of proficiency in Information and Communication Technologies (ICT) and their need for support with digital technologies show parallels with previous research (Narvekar, 2020; UNESCO, 2020b). The themes and sub-themes related with "Preschool teachers' pedagogical challenges during the COVID-19 pandemic", demonstrate relationally the economic, technological, family, and teacher dimensions of the COVID-19 phenomenon (UNESCO 2020b), as well as children's access to and use of technology (Dong \& Mertala 2020; Dong et al. 2020), and the support required for distance education (European Disability Forum, 2020).

\section{Conclusion}

This study, which examines preschool teachers' experiences and views on the distance education process during the quarantine brought on by the COVID-19 pandemic, was conducted with a total of 11 preschool teachers, 10 female and 1 male, who have professional experiences between 3 to 19 years. The data obtained from the interview forms filled out by the participating teachers were analyzed and three general themes were reached: challenges in the education process, views on the educational policies under the new normal, and expectations for the improvement of distance education. The themes, which explain "Preschool teachers' pedagogical challenges during the COVID-19 pandemic", based on the qualitative content analyses in the context of phenomenology design to the current study findings. The themes and their subthemes are as follows: The theme "challenges in the distance education process" contains the sub-themes of children, teachers, and parents, the theme "views about educational policy in new normal" contains the sub-themes of technological infrastructure problems, unpreparedness, and negative attitudes, the theme "expectations for the improvement of distance education" contains the sub-themes of teacher training, effective family involvement activities, and technology-based programs.

\section{Limitations and Implications for Further Research}

Although the interview forms enable in-depth findings, their one-dimensional nature poses a limitation to the diversity of data collection.

We recommend that similar studies can be conducted in which the sample group consists of parents. It is also recommended to conduct mixed-method studies in which data and sample groups are diversified.

\section{Declarations}

Editorial Acknowledgements: The editorial process and editorial decision were carried out and recorded by Dr. Meryem Demir Güdül. The paper was submitted by the first author and after completing the review process the first author asked to add the second author to the paper by signed letter. The process of the paper was carried out as doubleblinded according to the COPE's Best Practice Guidelines.

Authors' contributions: Both authors have an equal contribution.

Competing interests: The authors declare that they have no competing interests. 
Ethics approval and consent to participate: The ethical permission form number is 2020.52 and was signed by the chair of the ethics committee of the Istanbul Kültür University in 19 August 2020.

Funding: No funding was used for this study.

\section{References}

Abuhammad, S. (2020). Barriers to distance learning during the COVID-19 outbreak: A qualitative review from parents' perspective. Heliyon, 6(11), e05-482. https://doi.org/10.1016/j.heliyon.2020.e05482

Alan, Ü. (2021). Distance education during the covid-19 pandemic in Turkey: Identifying the needs of early childhood educators. Early Childhood Education Journal, 49, 987-994. https://doi.org/10.1007/s10643-021$\underline{01197-\mathrm{y}}$

Andrew, A., Cattan, S., Farquharson, C., Kraftman, L., Krutikova, S., Phimister, A., \& Sevilla, A. (2020). Inequalities in Children's Experiences of Home Learning during the COVID-19 Lockdown in England. Fiscal Studies, 41(3), 653-683. https://doi.org/10.1111/1475-5890.12240

Arcia, G. J., De Hoyos Navarro, R. E., Patrinos, H. A., Sava, A., Shmis, T., Teixeira, J. E. N. (2021). Learning Recovery after COVID-19 in Europe and Central Asia: Policy and Practice (English). World Bank Group. http://documents.worldbank.org/curated/en/836481622436593904/Learning-Recovery-after-COVID-19in-Europe-and-Central-Asia-Policy-and-Practice

Atiles, J. T., Almodóvar, M., Chavarría Vargas, A., Dias, M. J., \& Zúñiga León, I. M. (2021). International responses to COVID-19: challenges faced by early childhood professionals. European Early Childhood Education Research Journal, 29(1), 66-78. https://doi.org/10.1080/1350293X.2021.1872674

Barnett, W. S., Grafwallner, R., \& Weisenfeld, G. G. (2021). Corona pandemic in the United States shapes new normal for young children and their families. European Early Childhood Education Research Journal, 29(1), 109-124. https://doi.org/10.1080/1350293X.2021.1872670

Bayrakdar, S., \& Guveli, A. (2020). Inequalities in home learning and schools' provision of distance teaching during school closure of COVID-19 lockdown in the UK (No. 2020-09). ISER Working Paper Series. No. 2020-09, University of Essex, Institute for Social and Economic Research (ISER), Colchester, Essex. https://www.econstor.eu/bitstream/10419/227790/1/1703719352.pdf

Beckman, K., Bennett, S., \& Lockyer, L. (2019). Reproduction and transformation of students' technology practice: The tale of two distinctive secondary student cases. British Journal of Educational Technology, 39, 346. https://doi.org/10.1111/bjet.12736

Bernard, H. R. (2002). Research methods in anthropology: Qualitative and quantitative approaches (3rd ed.). Alta Mira Press

Chen, J., \& Chang, C. (2006). Using computers in early childhood classrooms: Teachers' attitudes, skills and practices. Journal of Early Childhood Research, 4(2), 169-188. https://doi.org/10.1177/1476718X06063535

Creswell, J. W. (2007). Qualitative inquiry and research design: Choosing among five traditions. SAGE Publications.

Creswell, J. W. (2014). Research Design: Qualitative, quantitative, and mixed methods approaches (4th ed.). SAGE Publications.

Creswell, J. W., \& Brown, M. L. (1992). How chairpersons enhance faculty research: A grounded theory study. The Review of Higher Education, 16(1), 41-62. https://doi.org/10.1353/rhe.1992.0002

Creswell, J. W., \& Plano Clark, V. L. (2011). Designing and conducting mixed method research (2nd ed.). SAGE Publications.

Creswell, J. W., Hanson, W. E., Clark, V. L., Plano, C., \& Morales, A. (2007). Qualitative research designs: Selection and implementation. The Counseling Psychologist, 35(2), 236-264. 
https://doi.org/10.1177/0011000006287390

Dong, C., \& Mertala, P. (2019). It is a tool, but not a 'must': early childhood preservice teachers' perceptions of ICT and its affordances. Early Years, 1-16. https://doi.org/10.1080/09575146.2019.1627293

Dong, C., Cao, S., \& Li, H. (2020). Young children's online learning during COVID-19 pandemic: Chinese parents' beliefs and attitudes. Children and Youth Services Review, 118, 105440. https://doi.org/10.1016/j.childyouth.2020.105440

Downe-Wamboldt, B. (1992). Content analysis: Method, applications and issues. Health Care for Women International, 13, 313-321. https://doi.org/10.1080/07399339209516006

Elo, S., \& Kyngäs, H. (2008). The qualitative content analysis process. Journal of Advanced Nursing, 62, 107-115. https://doi.org/10.1111/j.1365-2648.2007.04569.x

Elo, S., Kääriäinen, M., Kanste, O., Pölkki, T., Utriainen, K., \& Kyngäs, H. (2014). Qualitative content analysis: A focus on trustworthiness. SAGE Open. https://doi.org/10.1177/2158244014522633

European Disability Forum. (2020). Open letter to leaders at the EU and EU Countries: Covid-19 disability inclusive response. https://www.edf-feph.org/newsroom-news-open-letter-leaders-eu-and-eu-countries-covid19-disability-inclusive-response/

Fedynich, L. V. (2014). Teaching beyond the classroom walls: The pros and cons of cyber learning. Journal of Instructional Pedagogies, 13. https://files.eric.ed.gov/fulltext/EJ1060090.pdf

Garbe, A., Ogurlu, U., Logan, N., \& Cook, P. (2020). COVID-19 and remote learning: Experiences of parents with children during the pandemic. American Journal of Qualitative Research,4(3), 45-65. https://doi.org/10.29333/ajqr/8471

Giorgi, A. (2009). The descriptive phenomenological method in psychology: A modified Husserlian approach. Duquesne University Press.

Hammarberg, K., Kirkman, M., \& de Lacey, S. (2016). Qualitative research methods: when to use them and how to judge them. Human Reproduction, 31(3), 498-501. https://doi.org/10.1093/humrep/dev334

Hincapié, H., López-Boo, F., \& Rubio-Codina, M. (2020). The High Cost of COVID - 19 for Children Strategies for mitigating its impact in Latin America and the Caribbean. Inter-American Development Bank, 1-16. https://publications.iadb.org/publications/english/document/The-High-Cost-of-COVID-19-forChildren-Strategies-for-Mitigating-its-Impact-in-Latin-America-and-the-Caribbean.pdf

Hohlfeld, T. N., Ritzhaupt, A. D., \& Barron, A. E. (2010). Connecting schools, community, and family with ICT: Four-year trends related to school level and SES of public schools in Florida. Computers \& Education, 55, 391-405. https://doi.org/10.1016/j.compedu.2010.02.004

Holland, B. (2018). From digital divide to innovation divide? EducationWeek. https://blogs.edweek.org/edweek/edtechresearcher/2018/09/from digital divide to innovation divide.html

Hollingworth, S., Mansaray, A., Allen, K., \& Rose, A. (2011). Parents' perspectives on technology and children's learning in the home: Social class and the role of the habitus. Journal of Computer Assisted Learning, 27, 347-360. https://doi.org/10.1111/j.1365-2729.2011.00431.x

Hu, B. Y., Johnson, G. K., Teo, T., \& Wu, Z. (2020). Relationship between screen time and Chinese children's cognitive and social development. Journal of Research in Childhood Education, 34(2), 183-207. https://doi.org/10.1080/02568543.2019.1702600

Human Right Watch. (2021). "Years Don't Wait for Them" Increased inequalities in children's right to education due to the covid-19 pandemic. https://www.hrw.org/sites/default/files/media 2021/05/global covideducation0521 web.pdf 
Husserl, E. (1913/1983). Ideas pertaining to a pure phenomenology and to a phenomenological philosophy. First book: General introduction to a pure phenomenology (Trans. F. Kersten). Nijhojf Publishers.

Inan, H. Z. (2021). Challenges of Distance/Online and Face-to-Face Education in the New Normal: Experiences of Reggio Emilia-Inspired Early Childhood Educators in Turkey. Pedagogical Research, 6(1), em0086. https://doi.org/10.29333/pr/9304

Jain, S., Lall, M., \& Singh, A. (2021). Teachers' voices on the impact of COVID-19 on school education: Are edtech companies really the panacea?. Contemporary Education Dialogue, 18(1), 58-89. https://doi.org/10.1177/0973184920976433

Kalogiannakis, M. (2010). Training with ICT for ICT from the trainer's perspective. A local ICT teacher training experience. Education and Information Technologies, 15(1), 3-17. https://doi.org/10.1007/s10639-008-9079-3

Kerry, T., \& Farrow, J. (1996). Changes in initial teacher training: Students' perceptions of the effectiveness of school-based mentoring over time. Educational Studies, 22, 99-110. https://doi.org/10.1080/0305569960220108

Kim, J. (2020). Learning and teaching online during Covid-19: Experiences of student teachers in an early childhood education practicum. International Journal of Early Childhood, 52(2), 145-158. https://doi.org/10.1007/s13158-020-00272-6

Koyuncu, F., \& Düşkün, Y. (2020). Eğitim izleme raporu 2020: Öğretmenler. Ĕ̆itim Reformu Girişimi. https://www.egitimreformugirisimi.org/egitim-izleme-raporu-2020-ogretmenler/

Lau, E. Y. H., \& Lee, K. (2020). Parents' views on young children's distance learning and screen time during COVID-19 class suspension in Hong Kong. Early Education and Development, 1-18. https://doi.org/10.1080/10409289.2020.1843925

Lincoln, Y. S., \& Guba, E. G. (1985). Naturalistic inquiry. SAGE Publications. https://doi.org/10.1016/0147$\underline{1767(85) 90062-8}$

Lindahl, M. G., \& Folkesson, A. M. (2012). ICT in preschool: Friend or foe? The signifcance of norms in a changing practice. International Journal of Early Years Education, 20(4), 422-436. https://doi.org/10.1080/09669760.2012.743876

Malta Campos, M., \& Vieira, L. F. (2021). COVID-19 and early childhood in Brazil: Impacts on children's wellbeing, education and care. European Early Childhood Education Research Journal, 29(1), 125-140. https://doi.org/10.1080/1350293X.2021.1872671

Mantovani, S., Bove, C., Ferri, P., Manzoni, P., Cesa Bianchi, A., \& Picca, M. (2021). Children 'under lockdown': voices, experiences, and resources during and after the COVID-19 emergency. Insights from a survey with children and families in the Lombardy region of Italy. European Early Childhood Education Research Journal, 29(1), 35-50. https://doi.org/10.1080/1350293X.2021.1872673

Marton, F. (1981). Phenomenography-describing conceptions of the world around us. Instructional Science, 10(2), 177-200. https://doi.org/10.1007/BF00132516

Merriam, S. B. (2009). Qualitative research: A guide to design and implementation. Jossey-Bass.

MoNE. (2020a). Okul öncesi eğitim ve ilkokul birinci sımı öğrencileri için uyum eğitimine ve yüz yüze eğitime ilişkin açıklamalar.

https://tegm.meb.gov.tr/meb iys dosyalar/2020 09/17194705 Okul Oncesi ve 1. SYnYf Uyum ve Y uz Yuze EYitim.pdf

MoNE. (2020b). Okul öncesi eğitim kurumlarında yüz yüze eğitim. https://ookgm.meb.gov.tr/meb iys dosyalar/2020 11/20133842 okul-oncesi-egitim-kurumlarindayuz-yuze-egitim.pdf 
Moustakas, C. (1994). Phenomenological research methods. SAGE Publication. https://doi.org/10.4135/9781412995658

Mudi, A. (2020). Teaching in the time of Coronavirus. Retrieved from https://livewire.thewire.in/personal/teaching-in-the-times-of-coronavirus/

Murgatrotd, S. (2020, March). COVID-19 and Online learning. ResearchGate. http://dx.doi.org/10.13140/RG.2.2.31132.85120

Naceva, B., Galevski, M., \& Kelly, M. (2020). Read@Home: Effective partnership to reach vulnerable children in north Macedonia. Blog Post, December 17. World Bank Blogs. https://blogs.worldbank.org/education/readhome-effective-partnerships-reach-vulnerable-childrennorth-macedonia.

Narvekar, H. N. (2020). Educational concerns of children with disabilities during COVID-19 pandemic. Indian Journal of Psychiatry, 62(5), 603. https://doi.org/10.4103/psychiatry.IndianJPsychiatry 58520

Palinkas, L. A., Horwitz, S. M., Green, C. A., Wisdom, J. P., Duan, N., \& Hoagwood, K. (2015). Purposeful Sampling for Qualitative Data Collection and Analysis in Mixed Method Implementation Research. Administration and Policy in Mental Health, 42(5), 533-544. https://doi.org/10.1007/s10488-013$\underline{0528-\mathrm{y}}$

Parczewska, T. (2020). Difficult situations and ways of coping with them in the experiences of parents homeschooling their children during the COVID-19 pandemic in Poland. Education 3-13, 1-12. https://doi.org/10.1080/03004279.2020.1812689

Patton, M. Q. (2002). Qualitative research \& evaluation methods (3rd ed.). SAGE Publications.

Pavlenko, G. V., \& Pavlenko, A. I. (2020, December). Impact of COVID-19 Lockdown on the Readiness of Preschool Educators for Distance Learning. In 2nd International Scientific and Practical Conference on Digital Economy (ISCDE 2020) (pp. 163-168). Atlantis Press. https://doi.org/10.2991/aebmr.k.201205.026

Pokhrel, S., \& Chhetri, R. (2021). A literature review on impact of covid-19 pandemic on teaching and learning. Higher Education for the Future, 8(1), 133-141. https://doi.org/10.1177/2347631120983481

Povey, J., Campbell, A. K., Willis, L.-D., Haynes, M., Western, M., Bennett, S., Antrobus, E., \& Pedde, C. (2016). Engaging parents in schools and building parent-school partnerships: The role of school and parent organization leadership. International Journal of Educational Research, 79, 128-141. https://doi.org/10.1016/j.ijer.2016.07.005

Quezada, R. L., Talbot, C., \& Quezada-Parker, K. B. (2020). From bricks and mortar to remote teaching: A teacher education program's response to COVID-19. Journal of Education for Teaching, 46(4), 472-483. https://doi.org/10.1080/02607476.2020.1801330

Rieble-Aubourg, S., \& Viteri, A. (2020). COVID-19: Are we prepared for online learning? (Brief 20). Inter-American Development Bank. https://publications.iadb.org/publications/english/document/CIMA-Brief-20COVID-19-Are-We-Prepared-for-Online-Learning.pdf

Samuelsson, I. P., Wagner, J. T., \& Ødegaard, E. E. (2020). The coronavirus pandemic and lessons learned in preschools in Norway, Sweden and the United States: OMEP Policy forum. International journal of early childhood, 52(2), 129-144. https://doi.org/10.1007/s13158-020-00267-3

Schreier, M. (2012). Qualitative content analysis in practice. SAGE Publications.

Spinelli, M., Lionetti, F., Pastore, M., \& Fasolo, M. (2020). Parents' stress and children's psychological problems in families facing the COVID-19 outbreak in Italy. Frontiers in Psychology, 11, 1713. https://doi.org/10.3389/fpsyg.2020.01713

Spradley, J. P. (1979). The ethnographic interview. Waveland Press. 
Staupe-Delgado, R., \& Kruke, B. I. (2018). Preparedness: Unpacking and clarifying the concept. Journal of Contingencies and Crisis Management, 26(2), 212-224. https://doi.org/10.1111/1468-5973.12175

Stites, M. L., Sonneschein, S., \& Galczyk, S. H. (2021). Preschool parents' views of distance learning during COVID-19. Early Education and Development, 1-17. https://doi.org/10.1080/10409289.2021.1930936

UNESCO. (2020a). Startling digital divides in distance learning emerge. https://en.unesco.org/news/startlingdigital-divides-distance-learning-emerge

UNESCO. (2020b). Distance learning strategies in response to COVID-19 school closures. https://unesdoc.unesco.org/ark:/48223/pf0000373305

UNESCO. (2021). COVID-19 impact on education. https://en.unesco.org/covid19/educationresponse

UNICEF. (2020). COVID-19: Are children able to continue learning during school closures. A Global Analysis of the Potential reach of Remote Learning Polices Using Data from, 100, 17. https://data.unicef.org/resources/remote-learning-reachability-factsheet/

UNICEF. (2021). Education and COVID-19. https://data.unicef.org/topic/education/covid-19/\#status

United Nations. (2020a). Policy brief: The impact of covid-19 on children. https://unsdg.un.org/sites/default/files/2020-04/160420 Covid Children Policy Brief.pdf

United Nations. (2020b). Policy brief: Education during COVID-19 and beyond. https://unsdg.un.org/resources/policy-brief-education-during-covid-19-and-beyond

US Department of Education. (2017). Re-imagining the role of technology in education: 2017 national education technology plan update. https://tech.ed.gov/files/2017/01/NETP17.pdf

Visnjic-Jevtic, A., Varga Nagy, A., Ozturk, G., Şahin-Sak, İkbal T., Paz-Albo, J., Toran, M., \& Sánchez-Pérez, N. (2021). Policies and practices of early childhood education and care during the COVID-19 pandemic: Perspectives from five countries. Journal of Childhood, Education \& Society, 2(2), 200-216. https://doi.org/10.37291/2717638X.202122114

Wedenoja, L. (2020). What to expect when you weren't expecting online classes. Rockefeller Institute of Government. https://rockinst.org/blog/what-to-expect-when-you-werent-expecting-online-classes/

WHO. (2020a). WHO Director General's opening remarks at the mission briefing on COVID-19. https://www.who.int/dg/speeches/detail/who-director-general-s-openingremarks-at-the-missionbriefing-on-covid-19---12-march-2020

WHO. (2020b). Considerations for school-related public health measures in the context of COVID-19. Annex to Considerations in adjusting public health and social measures in the context of COVID-19. WHO Team. https://who.int/publications/i/item/considerations-for-school-related-public-health-measures-in-thecontext-of-covid-19

World Bank. (2021). Read@Home. https://www.worldbank.org/en/topic/education/brief/read-at-home

Yıldırım, B. (2021). Preschool education in Turkey during the Covid-19 pandemic: A phenomenological study. Early Childhood Education Journal, 49, 947-963. https://doi.org/10.1007/s10643-021-01153-w 